\title{
BMJ Open Hospital managers' perspectives with implementing quality improvement measures and a new regulatory framework: a qualitative case study
}

\author{
Sina Furnes Øyri (D) , ${ }^{1}$ Geir Sverre Braut (D) , ${ }^{2,3,4}$ Carl Macrae, ${ }^{1,5}$ Siri Wiig ${ }^{1}$
}

To cite: Øyri SF, Braut GS, Macrae C, et al. Hospital managers' perspectives with implementing quality improvement measures and a new regulatory framework: a qualitative case study. BMJ Open 2020;10:e042847. doi:10.1136/ bmjopen-2020-042847

- Prepublication history and additional material for this paper is available online. To view these files, please visit the journal online (http://dx.doi.org/10. 1136/bmjopen-2020-042847).

Received 17 July 2020 Revised 12 November 2020 Accepted 18 November 2020

Check for updates

(C) Author(s) (or their employer(s)) 2020. Re-use permitted under CC BY-NC. No commercial re-use. See rights and permissions. Published by BMJ.

For numbered affiliations see end of article.

Correspondence to

Sina Furnes Øyri;

sina.f.oyri@uis.no

\section{ABSTRACT}

A new regulatory framework to support local quality and safety efforts in hospitals was introduced to the Norwegian healthcare system in 2017. This study aimed to investigate hospital managers' perspectives on implementation efforts and the resulting work practices, to understand if, and how, the new Quality Improvement Regulation influenced quality and safety improvement activities.

Design This article reports one study level (the perspectives of hospital managers), as part of a multilevel case study. Data were collected by interviews and analysed according to qualitative content analysis. Setting Three hospitals retrieved from two regional health trusts in Norway.

Participants 20 hospital managers or quality advisers selected from different levels of hospital organisations. Results Four themes were identified in response to the study aim: (1) adaptive capacity in hospital management and practice, (2) implementation efforts and challenges with quality improvement, (3) systemic changes and (4) the potential to learn. Recent structural and cultural changes to, and development of, quality improvement systems in hospitals were discovered (3). Participants however, revealed no change in their practice solely due to the new Quality Improvement Regulation (2). Findings indicated that hospital managers are legally responsible for quality improvement implementation and participants described several benefits with the new Quality Improvement Regulation (2). This related to adaptation and flexibility to local context, and clinical autonomy as an inevitable element in hospital practice (1). Trust and a safe work environment were described as key factors to achieve adverse event reporting and support learning processes (4).

Conclusions This study suggests that a lack of time, competence and/or motivation, impacted hospitals' implementation of quality improvement efforts. Hospital managers' autonomy and adaptive capacity to tailor quality improvement efforts were key for the new Quality Improvement Regulation to have any relevant impact on hospital practice and for it to influence quality and safety improvement activities.

\section{INTRODUCTION}

After years of regulatory interventions, management strategies and policy-making,
Strengths and limitations of this study

- The main strength of this study is the novel approach of involving hospital managers' perspectives in healthcare regulation research, as they are both legally and practically responsible for improving quality and safety.

- Most participants had substantial clinical experience and/or still worked in the clinic environment, in addition to having management responsibilities. This provided our study with valuable insight into the complexity in hospital management.

- The study did not include all four regional health trusts in Norway in its data.

- Variations in support systems and routines for training managers differ from region to region and may have implicitly or explicitly impacted participants' views and experiences with quality and safety improvement and in turn potentially influenced findings.

- The individual interviews only focused on hospital managers own reflections and no actual, observational studies of practice, implementation or change where conducted.

improving quality and safety of healthcare systems remain high on political agendas around the world. Still, patient harm is listed as the world's 14 biggest health burden along with illnesses such as malaria and tuberculosis. ${ }^{1-5}$ The process of improving quality and safety has traditionally involved different dimensions, for instance clinical effectiveness, patient centeredness and care coordination. ${ }^{6}$ If addressed, these dimensions seek to achieve an optimal healthcare system ${ }^{6}$ (see table 1 for definitions of 'quality' and 'safety'). A system perspective on quality improvement and involvement of stakeholders at different levels are portrayed as key in efforts to improve patient outcomes, system performance and professional development (learning). ${ }^{78}$ Moreover, management of and leadership in healthcare is reckoned one of 


\begin{tabular}{|c|c|}
\hline Quality & $\begin{array}{l}\text { We adopt the conceptualisation introduced by the Institute of Medicine defining quality through six dimensions: clinical } \\
\text { effectiveness, patient safety, patient centeredness, care coordination, efficiency, timeliness and equity. }{ }^{6100}\end{array}$ \\
\hline Regulation & $\begin{array}{l}\text { We define the phenomenon of regulation generally as a governmental mechanism and specifically as the Norwegian regulatory } \\
\text { framework; regime referred to in this article as the Quality Improvement Regulation with a capital 'R' in 'regulation'. Different } \\
\text { regulatory activities exist, with different interventionistic approaches; acts of law, internal control, self-regulation, external } \\
\text { inspection; supervision. }{ }^{64101}\end{array}$ \\
\hline Risk & $\begin{array}{l}\text { We define risk as the consequence of any activity with associated uncertainty; the possibility that an event or human action } \\
\text { could negatively affect valuables. }{ }^{102} \text { For instance: a specific patient injury that possibly can occur during or after surgery, but with } \\
\text { uncertainty to whether it will happen, when it will occur and what consequences it will lead to. }{ }^{103}\end{array}$ \\
\hline Safety & $\begin{array}{l}\text { We understand safety as one dimension of quality. }{ }^{104} \text { And, we apply it as the preventive measures put in place to reduce } \\
\text { potential adverse events and the proactive measures that seeks to reduce the negative consequences and maintain its regular } \\
\text { performance. }{ }^{105}\end{array}$ \\
\hline
\end{tabular}

the fundamental elements to quality and safety, particularly related to implementation of improvement activities. ${ }^{9}{ }^{10}$ Inquiries into major healthcare failures, such as the Mid Staffordshire inquiry in 2013 and the Morecambe Bay inquiry in 2015 in the UK, revealed poor management and lack of safety oversight as common contributors to quality failures. ${ }^{12}$ A progress report from 2018 added to these findings, calling for stronger management commitment in healthcare, amplifying how quality and safety should be incorporated into operational culture. ${ }^{4}$ Internationally, increased attention has been brought to involvement of clinicians in management roles and highlighted the key role top managers play in providing support to lower level managers. ${ }^{11}{ }^{12}$ In Norway, hospital organisations are required to ensure their employees have relevant competences and training. Current leadership programmes and training regularly include learning about quality improvement methods and systematics. ${ }^{513} 14$ Yet, recent research has indicated that to make quality improvement a thriving part of daily management practice, it needs to be supported by a strategic commitment to improvement, time to spend on improvement, and a culture that supports managers and clinicians working together. ${ }^{15}$

Prior research on healthcare regulation and its relation to improvements in organisational behaviour, including conduction of external inspection, has shown inconsistent outcomes in terms of its effectiveness ${ }^{16-21}$ (see table 1 for this study's conceptualisation of 'regulation' and regulatory activities). Several previous studies have explored healthcare organisations' resilience potentials, including their capacity to adapt, but to date few multilevel studies link adaptive capacity with regulatory activities. ${ }^{22-31}$ Others have highlighted that actively engaged participants from all organisational levels in healthcare are important, stressing how active improvement depends on leadership, also in the sense of recognising conditions that require flexibility. ${ }^{72}$ The latter links management of quality improvement to management of adaptive capacity. Thus, attention should be paid to the development process of designing regulation that enables flexibility and supports adaptive capacity, by requesting non-detailed preferences or performance goals, especially since this may lead to a bottom-up perspective rather than top-bottom. ${ }^{16}{ }^{31-35}$
In 2017, a new regulatory framework to support local quality and safety efforts was introduced in the Norwegian healthcare system. ${ }^{13}$ This framework, the Regulation on Management and Quality Improvement in the Healthcare Services (referred to as the Quality Improvement Regulation) focuses on developing the capacity of healthcare organisations to continually improve quality and safety by constructing non-detailed goals for risk management ${ }^{13}$ (see table 1 for definition of 'risk'). Although the Quality Improvement Regulation is considered one of the most important governmental tools to support local quality and safety efforts in hospitals, ${ }^{5} 3637$ its impact on the healthcare services is still unknown from all perspectives (regulatory inspectors, hospital managers and healthcare personnel). The role of hospital managers is particularly important as they are stakeholders situated in the middle of governmental expectations and requirements, administrative demands and clinical practice.

Through the Quality Improvement Regulation, the regulators require hospital organisations to establish a system for risk management and responsibility. Its design embeds a structure of Plan, Do, Study, Act (PDSA), a fourstep management methodology for quality improvement activities developed by Deming. ${ }^{38}$ The Quality Improvement Regulation requires hospitals to plan for and establish systems to minimise risks, and to discover adverse events before they have consequences for the patients. Furthermore, it requires hospital managers to handle, correct and evaluate adverse events and failures. Accordingly, this study aims to investigate hospital managers' perspectives on implementation efforts and the resulting work practices, to understand if, and how, the new Quality Improvement Regulation influenced quality and safety improvement activities.

\section{Contextual background of the Norwegian regulatory regime for quality improvement}

Several governmental initiatives have been launched in Norway in recent years in order to facilitate the hospitals' continuous attention to patient safety and to increase the overall quality in the healthcare services they offer. The initiatives include annual quality and patient safety reports to the Norwegian Parliament (White Papers), national quality indicators, the previous National 
Strategy for Quality Improvement in Health and Social Services (2005-2015), a patient safety campaign (20102013), followed by a the national 5-year 'Patient Safety Program, ${ }^{39-41}$ The latter was launched in 2014 , as a broad scale effort to reduce patient injuries. ${ }^{40}{ }^{41}$ This programme (2014-2018) aimed at targeting several areas where it was believed to be crucial to increase care quality, including 'Safe Surgery' and 'Management of Patient Safety'. It quantified several objectives-for instance to reduce infections, to improve survival rate and to improve patient safety culture. ${ }^{40}$ Specific improvement projects were developed to meet relevant challenges in specific hospital settings, and hospitals were expected to incorporate the different initiatives to their daily work schedules. The recent national action plan for quality and patient safety (2019-2023) maintains attention on structural and cultural dimensions in quality and safety improvement. ${ }^{5}$ In addition to these initiatives, previously conducted external hospital supervision across health regions in Norway have identified several challenges to systematic quality improvement ${ }^{42-47}$ :

- Lack of adequate management responsibility and competencies.

- Lack of structure to ensure coworkers have prudent professional qualifications.

- Lack of systematic collecting of and evaluation of risks, vulnerabilities and adverse events.

- Lack of implementation of planned work tasks.

- Lack of evaluation of improvement efforts, post implementation.

- Lack of familiarity with and implementation of the previous regulatory framework for quality and safety management 'the Internal Control Regulations', $2002 .{ }^{48}$

Moreover, hospital managers' attitudes, values and organisational culture for learning were associated with non-compliance with governmental requirements. ${ }^{42-46}$ These challenges and issues associated with implementation of quality improvement measures in hospitals formed an important backdrop to the questions that were asked in our study.

\section{Content and design of the quality improvement regulation}

The development and enactment of the Quality Improvement Regulation was thus the Government's response to these challenges and launched in parallel with some of the other initiatives described above. The regulatory focus on the managerial level and the role of managers in risk management and quality improvement increased significantly with the new Quality Improvement Regulation compared with the previous Internal Control Regulations, as it (in a separate provision, cf. section 3) specifies the managerial responsibility to improve quality. The obligation to delegate tasks from one management level to another in daily work operations was specified. Moreover, one new substantial provision was added (cf. $\S 8$ litra f): the obligation to systematically evaluate risk management and quality improvement measures (yearly). The Quality
Improvement Regulation's purpose is hence twofold: by explicitly stating managerial responsibilities it aims at improving managerial practices, whereas the PDSA methodology aims at organising the services in ways that improve clinical care. In table 2, we illustrate details on the Quality Improvement Regulation's regulatory PDSA design. Two specific examples of activities are given for each of the steps, all retrieved from the guidelines document relating to the Quality Improvement Regulation. ${ }^{49}$

\section{The Norwegian specialised healthcare system}

Four regional health trusts across Norway are responsible for implementing the national policies and regulations, and planning, organising, governing and coordinating all subordinated local health trusts, including the hospitals in their region (see box 1 displaying key numbers in the Norwegian specialist healthcare system)..$^{50}$ Every hospital should be organised with a responsible manager at all organisational levels. ${ }^{14}$ For each organisational unit in the hospital (eg, clinic (division or similar), department or equivalent, and sections), one manager with overall responsibility for the unit, both administratively and professionally should be appointed. ${ }^{52}$

\section{METHODS}

\section{Study design and setting}

This article represents one substudy that is part of a broader qualitative, multilevel design single embedded case study, investigating regulatory quality improvement implementation and work across three levels of the specialised Norwegian healthcare system. ${ }^{37} 53$ The case was defined as the design, implementation and enactment of the Quality Improvement Regulation and its impact on management and quality improvement across three organisational levels in two health regions. Specifically, the multilevel study involves three levels of stakeholders: macrolevel (governmental bodies of regulation), mesolevel (County Governors' inspectors-regional supervision) and microlevel (three hospitals selected from two regional health trusts in Norway). To illustrate, figure 1 outlines the three system levels involved in the overall case study, whereas the microlevel presented in this article is specifically marked.

According to a multilevel approach, different levels of stakeholders have different impact on the risk management process. ${ }^{54}$ These levels are interconnected through processes of information and decision-making, thus asking questions within three levels rather than within one single level, might help overcome single-level limitations. ${ }^{55}$ Moreover, a multilevel study design can contribute to reflect healthcare organisations as integrated wholes where the patterns among different stakeholders are a key area of investigation. ${ }^{56}$ Accordingly, this article presents the microlevel substudy, based on semistructured interviews with 20 Norwegian hospital managers and quality advisers. Macrolevel findings and mesolevel findings are presented in two separate research articles. ${ }^{37} 53$ 


\begin{tabular}{|c|c|c|}
\hline PDSA step & Key areas and improvement tasks & Examples of specific activities \\
\hline The duty to plan & $\begin{array}{l}\text { Plan tasks and activities } \\
\text { Gain overview of responsibility, laws, } \\
\text { regulations, guidelines and of deviations. } \\
\text { Gain overview of adverse events, risks } \\
\text { and areas of significant need for quality } \\
\text { improvement } \\
\text { Plan how to minimise these risks. }\end{array}$ & $\begin{array}{l}\text { Example 1: identify and discuss deviances reported to the } \\
\text { hospital's system for adverse event reporting. } \\
\text { Example 2: structured identification and analysis of the } \\
\text { last } 50 \text { mortalities at the relevant hospital, through medical } \\
\text { records. }\end{array}$ \\
\hline $\begin{array}{l}\text { The duty to } \\
\text { implement (do) }\end{array}$ & $\begin{array}{l}\text { Ensure that activities relevant regulations } \\
\text { and guidelines are known } \\
\text { Develop and implement procedures and } \\
\text { routines to reveal, correct and prevent } \\
\text { breach and violation of sound professional } \\
\text { practice and systematic quality improvement }\end{array}$ & $\begin{array}{l}\text { Example 1: conduct a weekly, } 15 \text { min interdisciplinary } \\
\text { meeting to visually display ideas for improving the quality } \\
\text { in areas where patient complaints exist. } \\
\text { Example 2: relevant department or unit leader conducts a } \\
\text { patient safety 'visit' with the objective of identifying risks } \\
\text { and possible areas for improvement and to encourage } \\
\text { collaboration between the management level and 'front- } \\
\text { line' clinicians. }\end{array}$ \\
\hline $\begin{array}{l}\text { The duty to } \\
\text { correct (act) }\end{array}$ & $\begin{array}{l}\text { Correct unsound practice and regulatory } \\
\text { violations } \\
\text { Ensure implementation of systematic quality } \\
\text { improvement efforts } \\
\text { Improve necessary procedures, instructions, } \\
\text { routines to reveal, correct violations }\end{array}$ & $\begin{array}{l}\text { Example 1: apply small-scale testing to ensure that recent } \\
\text { technology and new treatment is efficient. } \\
\text { Example 2: conduct a Pareto diagram/chart to uncover } \\
\text { what causes certain registered issues at the relevant } \\
\text { hospital unit. }\end{array}$ \\
\hline
\end{tabular}

\section{Participants}

The inclusion criteria were participants who currently worked as hospital managers or advisers to hospital managers, preferably with clinical experience, situated at all levels within the hospital organisations, for example, head of clinic, head of department, divisional manager. Out of 20 participants, 18 had authorisation and license as health personnel and clinical experience from hospital practice. Several of them still worked clinically. Four out of five advisers had previous hospital manager experience and were chosen to highlight the support system for managers in the selected hospitals.

Box 1 Key numbers in the Norwegian specialist healthcare system

\section{Key numbers}

- 1987263 million million patients treated and/or hospitalised in 2019..$^{106}$

- 114028 thousand people employed in the specialist healthcare services in $2018 .^{107}$.

- The overall level of staffing by higher level health personnel is relatively high, with more than $50 \%$ of hospital employees being either physicians or nurses/midwives. ${ }^{107}$.

- €2667 (Kr27 100 Norway) in operating expenses per inhabitant in 2018. ${ }^{106}$
Gender balance: 11 men and 9 women. See table 3 for participants' characteristics.

\section{Recruitment}

Participants were recruited from three different hospitals. Hospital one and two belonged to the same regional health trust, while hospital three belonged to a different regional health trust. These three hospitals were selected as they were affiliated with the three County Governors offices recruited at the mesolevel in the broader multilevel study. Relevant

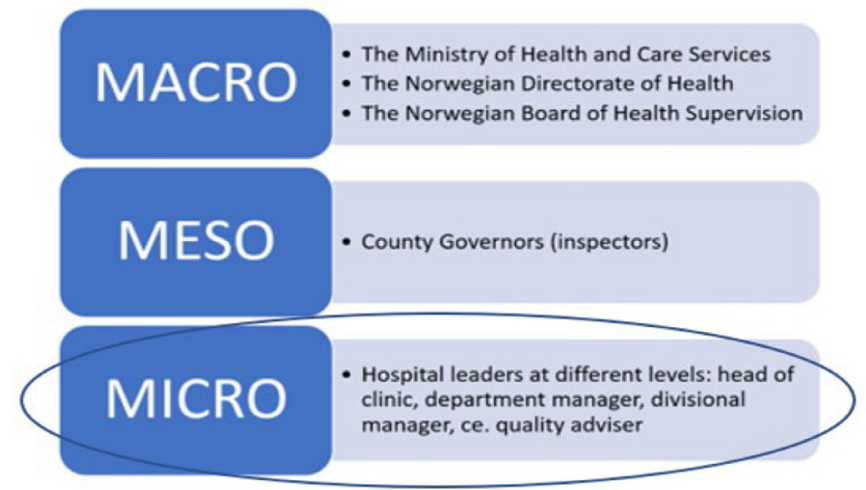

Figure 1 The system levels involved in the multilevel case study. 
Table 3 Participants' characteristics

\begin{tabular}{|c|c|c|c|}
\hline Participant & Educational background* & Position & $\begin{array}{c}\text { Organisation } \\
\text { and region }\end{array}$ \\
\hline 1 & M.D., specialist, $\mathrm{PhD}$ & Divisional manager & $A-1$ \\
\hline 2 & R.N., MSc in risk management & Adviser, quality and patient safety & $A-1$ \\
\hline 3 & Lawyer & Legal adviser, quality and patient safety & $A-1$ \\
\hline 4 & M.D. & Head of clinic & $A-1$ \\
\hline 5 & R.N., MSc in risk management & Adviser, quality; clinical coordinator & B-1 \\
\hline 7 & Lawyer & Deputy head of clinic & B-1 \\
\hline 8 & M.D., PhD & Medical director & $\mathrm{B}-1$ \\
\hline 9 & M.D., PhD & Head of research & $\mathrm{C}-2$ \\
\hline 10 & D.D.S., PhD & Head of clinic & $A-1$ \\
\hline 14 & R.N., specialist & Head of department & B-1 \\
\hline 15 & M.D., specialist; surgeon & Head of clinic & C-2 \\
\hline 16 & P.T., MSc in management & Adviser, quality & $\mathrm{C}-2$ \\
\hline 17 & R.N., specialist & Head nurse & B-1 \\
\hline 18 & M.D. & Senior adviser, quality and patient safety & C-2 \\
\hline 19 & M.D., PhD & Head of department & C-2 \\
\hline 20 & R.N., MSc in health management & Head of quality & C-2 \\
\hline
\end{tabular}

*M.D., medical doctor, R.N., registered nurse, D.D.S, doctor of dental surgery, P.T, physiotherapist.

participants were contacted by email; proposed participation in the study, of which all (except one) accepted the invitation to participate.

\section{Data collection}

All interviews were conducted during the spring of 2019, then transcribed. SFO conducted and audio recorded all interviews face to face, at the participants' workplace. Each interview had a duration of approximately 1 hour to 1 hour and $30 \mathrm{~min}$. Based on the preplanned semistructured interview guide (see online supplemental file 1), open-ended questions focused on areas of responsibility, work practices, training, implementation of quality improvement measures, regulatory flexibility, the role of supervision in improvement work and learning, experiences connected to structural development and attitudes, cooperation among different levels of government, management levels in hospitals and clinical, front-line personnel.

More specifically, questions were asked to determine if and how the Quality Improvement Regulation addressed some of the issues and challenges described in previous external inspections. The questions included for instance whether non-detailed risk management goals in the new regulatory framework facilitated flexibility in practical application and how managers experienced the systematic PDSA methodology (see preplanned questions in the online supplemental file 1). In addition, questions relating to communication and interaction among different system levels were asked to give insight into the regulator-regulatee interaction. The latter was particularly important to ascertain how hospital managers viewed the role of regulators and the new regulation, and the extent to which possible conflicts were reduced between government-level expectations and local-level, practices of managing quality improvement and safety.

Prior to the interviews, the participants received an information sheet informing them about the study's topic, methods and data protection, and the researcher's (SFO) credentials and occupation at the time of the study. Participants were subsequently requested to give their written consent. No preexisting relationship with any of the participants existed.

\section{Analysis}

Researcher SFO analysed the interview transcripts manually, using content analysis influenced by Graneheim and Lundman. ${ }^{57}$ This analytical process consisted of several steps. SFO initially read through all interviews and took notes of immediate thoughts that occurred after reading, before organising all interview transcripts into a matrix. Thereafter, SFO identified and condensed all meaning units, suggested codes and subcategories. Four themes emerged across the data. Researchers GBS and SW read all interview transcripts and participated in discussions about categories and themes, to ensure the data's reliability. ${ }^{58}$ Our data were relatively rich, and we reached saturation during the analysis, justifying the number of participants. 5960

Resilience in healthcare constitutes a valuable framework that helps to understand how systems can function and improve despite disruptions and adverse events. ${ }^{61}$ A core idea 
is that resilience is the ability of the healthcare system to adjust its functioning prior to, during, or following changes and disturbances, so that it can sustain required performance under both expected and unexpected conditions. ${ }^{62} 63$ Findings were therefore explained and interpreted by using resilience theory linked to adaptive capacity. ${ }^{63-67}$ The data were partly analysed inductively by identifying concepts within resilience in healthcare and partly deductively by using predetermined questions explicitly exploring resilience potentials. ${ }^{68}$

\section{RESULTS}

From our data of 20 interviews, we identified 4 themes: (1) adaptive capacity in hospital management and practice, (2) implementation efforts and challenges with quality improvement, (3) systemic changes, and (4) the potential to learn. All four themes are discussed below, along with illustrative participants' quotes (numbers in parentheses indicate the link to participants characteristics, cf. table 3).

\section{Theme I adaptive capacity in hospital management and practice}

Participants agreed that the Quality Improvement Regulation was designed in a way that supported flexibility, enabling managers to determine and adapt implementation efforts and quality improvement measures to their local context. This was portrayed as essential, partly due to the complexity in the system including different risks and elements (eg, postoperative complications, team coordination, complex procedures) of variation and uncertainty. Risk-based management was thus characterised as one of the favourable advantages with the new Quality Improvement Regulation, as it encourages managers to assess risks according to specifics and hallmarks in the relevant unit, department and clinic.

The Quality Improvement Regulation gives you room to maneuver because it has a generic design.

$$
\text { - Medical doctor, head of department (13) }
$$

After all, you are completely dependent on close dialogue with those who work (at the sharp end) and we as managers need to move closer to find out where we need to adjust and to discover the areas where things are not working.

$$
\text { - Medical doctor, head of clinic (11) }
$$

Participants argued that having a one size fits all solution is not easy, as improvising will always be necessary at a local level. They continued with describing that in a hospital you are not in control of your day because new situations occur, implying that it is impossible to anticipate every possible event. This is one of the main reasons for why implementation of new routines and procedures are challenging, participants claimed. They believed that the embedded risks would remain risks regardless of new regulatory requirements, illustrated by the fact that adverse events still occur despite new, improved routines and procedures. Adding to this, participants described how they worked on standardising procedures aiming to reduce some of the unwanted variation in their work but noted that methods of treatment and evidence evolve so quickly that procedures need constant updates. While the government sometimes presents a black and white solution, a procedure is only valid until good reasons exist to deviate from it, they noted.

There are so many different things that come up and occur, that it is not always easy to have a one size fits all solution. There is some improvisation sometimes, in how to approach a problem.

\section{- Medical doctor, head of department (12)}

For a very detailed procedure to work well, you must be able to predict all types of situations that the different medical practitioners may come across, and we do not always manage to predict that.

\section{- Medical doctor, adviser in quality and patient safety (18)}

Autonomy was described as a key flexibility feature in everyday hospital work, especially for physicians. However, high degrees of autonomy may sometimes compromise physicians' willingness to actively participate in systematic quality improvement work compared with the nursing profession, participants claimed.

They must get the impression of being involved inand to influence their daily work. To give a purely administrative order, like: "Now you must pull yourself together, you should do this and that", that approach will not do, they will boycott it.

\section{- Medical doctor, head of clinic (15)}

They also reported that the flexibility leaves the hospitals with the choice to implement whatever adverse event reporting system they choose. Furthermore, adaptive capacity to handle risks and challenges implies that hospitals are influenced by their own competences in terms of having the right personnel and training. Some participants even requested more strict support and correctives from their senior managers because that would indicate that their manager knew what sort of challenges they struggled with in their everyday work (eg, quality improvement efforts are added on top of their everyday workload, lack of good quality indicators, lack of personnel and time, information overload, lack of coordinated data systems).

I feel that we are free to express it (further up the hierarchy) if we experience that some efforts do not make sense to our work practices.

$$
\text { - Nurse, head of department (14) }
$$

Physicians hate to be controlled. At the same time, they write to the Ministry "we got to have some clear guidelines", so physicians both love and hate rules. And it's a schizophrenia that physicians have always had.

$$
\text { - Medical doctor, adviser in quality and patient safety (18) }
$$


Theme II implementation efforts and challenges with quality improvement

Our participants all agreed about the advantage and necessity of highlighting management responsibility in the new Quality Improvement Regulation. However, participants reported that most managers already have too many obligations and do not have time to prioritise systematic quality improvement efforts. Some even reported that many managers simply do not care about professional management and administering of their unit, department or clinic.

I think that the Quality Improvement Regulation is providing managers with an overall description of how a manager should act. You must do all these things that many people believe are obvious. And the Quality Improvement is kind of "stating the obvious".

- Medical doctor, adviser in quality and patient safety (18)

Although PDSA as a method was familiar to the hospitals prior to introducing the Quality Improvement Regulation, several participants argued that the systematic four phase process is not embedded in health personnel's work practice. They described all four phases as equally important but stressed that evaluation and restoring/ returning to a normal state are the most demanding to operationalise into reality.

The extent to which these (PDSA) circles work according to the intention: there are measures implemented, and then there is no follow-up of the decisions. There is a total lack of it, I would almost say.

\section{- Medical doctor, head of research (9)}

I do not know if I am able to articulate how I work specifically with the four (PDSA) elements (...) because it is quite different from one area to the next.

$$
\text { - Nurse, head of quality (6) }
$$

Participants believed that the Quality Improvement Regulation did not lead to change in their practice.

Some things have been done by the executive level, but the clinic managers have not addressed it.

$$
\text { - Nurse, quality coordinator (5) }
$$

Not directly linked (the introduction of the Quality Improvement Regulation and implementation of practical measures into clinical work). I cannot think of (episodes) where it was like "let us take a look at this (the Quality Improvement Regulation) and then start changing things".

$$
\text { - Nurse, Head of Quality (20) }
$$

Lack of understanding of what was referred to as 'internal jargon' in quality improvement and patient safety was believed to add to the burden and responsibilities of managers. However, several quality improvement measures were described, such as double check of medications, focus on communication in teamwork, reducing the number of hallway patients, questionnaire for patients' satisfaction, preoperative marking, and surgical checklists. The latter was described as the most difficult, yet most successful implementation measure.

Several participants referred to what they experienced to be a common, yet a false claim: that physicians are not concerned about or involved in quality improvement. A lot of the improvement methodology is present although it is not stated clearly or written down and most physicians do work unconsciously in accordance with the quality improvement methodology, participants reported.

\section{Theme III systemic changes}

Findings revealed both structural and cultural changes to, and development of, quality improvement systems in the hospitals. The structural quality improvement elements were described in terms of the establishment of different types of meetings, councils and committees (eg, patient safety and quality councils, network meetings, internal audit meetings) at the administrative and management levels in hospitals.

We have built a new structure of quality and patient safety units.

\section{- Lawyer, legal adviser in quality and patient safety (3)}

Furthermore, systems of adverse event reporting and systems for documentation of procedures, routines, guidelines were introduced, and constantly evaluated and improved. The latter was described as extremely challenging in everyday work, as the number of available documents felt overwhelming, and sometimes routines and procedures overlapped or were outdated.

It has been one of the most important things, the system for documentation, and we have been working intensely to clear away old routines, revise all routines and get them updated, especially since our new quality adviser started.

\section{- Lawyer, deputy head of clinic (7)}

In addition to hospital internal structural changes, participants described an increased governmental spotlight on patient safety in general and on managers' roles in reducing risks and enabling their employees to work safely and provide high quality care to patients. As a legal document, the Quality Improvement Regulation manifested this development, the participants explained.

We were probably more mature now in order to get that new Quality Improvement Regulation, and what I think is very nice is that it is to the point, three pages and it is kind of "this is how we should do it".

$$
\text { - Nurse, Head of Quality (20) }
$$

We are obliged to do an annual risk review, which we have never done before, and we believe that the (Quality Improvement) Regulation has helped us in turning the spotlight on that.

- Medical Director (8) 
All participants reported a cultural shift in improvement work over recent years. They described a change in attitudes towards the importance of continuous quality improvement and the systematic approach to it. Courses and training that used to be ignored by physicians, had gained attention, and increased its popularity, however support systems and routines varied among the study sites. Several participants also had experienced and expected a further shift with new generations of physicians approaching the field. This was explained partly due to the renewed curriculum introducing the methodology of systematic planning, acting, restoring and evaluation early on in their education.

(Quality improvement work) is not entirely new, but quite new. When I started as a surgeon, these were things that never came into view, so it's been a remarkable change, especially over the last ten years.

\section{- Medical doctor, head of clinic (15)}

Today, managers can hardly speak without having to mention the word patient safety. So, it's been an interesting development.

- Medical doctor, adviser in quality and patient safety (18)

\section{Theme IV the potential to learn}

To maintain high quality care, interpersonal trust among health personnel and institutional trust between hospital managers and governmental supervisory bodies is a necessity, participants argued. Explaining why adverse event reporting was still weak, participants highlighted a safe work environment. Participants felt that a healthy reporting regime emerges from a just culture, which in turn leads health personnel to feel confident that they will be taken care of if they make mistakes and if they report adverse events. Some noted that a systems-perspective to adverse events, supported by the Quality Improvement Regulation, was more frequently applied now compared with in previous supervision activities, contributing to the needed sense of confidence to openly discuss adverse events and risks.

And I think that in doing quality improvement and patient safety work, we need to recognise that the number one priority is to ensure that health personnel are confident that they will be taken care of if they make mistakes, and that they find themselves in a system that reduces the number of adverse events to a minimum.

\section{- Medical doctor, head of department (19)}

In general, organisational, and individual learning was described as challenging and even more so learning across departments, clinics and between hospitals. Participants explained that it was difficult to learn from adverse events during normal work operations due to time pressures, nor did health personnel always have the motivation to do it.

We are part of an intellectual organisation, right, that is what drives us forward. After all, it is about our minds. To be able to change things you must get all these minds on board. Otherwise, everything stops.

\section{- Medical doctor, head of clinic (15)}

Since it is difficult to learn from adverse events, and the time is lacking-participants argued that it is difficult to learn from successful outcomes too. Implementation of the Quality Improvement Regulation did not change this.

We do have regular meetings within the clinic and across departments, so we learn a lot and it is our responsibility to somehow pass it on to our department. I don't think there is a good system for that, but I don't know how it could be resolved. The challenge is the amounts of information which I must communicate further down the system, to my employees, but they work shifts and are not necessarily checking their email every day.

\section{- Head nurse (17)}

As a response to questions about the interplay between hospitals and supervisory bodies, most participants emphasised that supervision could be useful and help the managers to focus on certain risk areas or challenging work practices. However, participants gave examples of less helpful episodes, such as inspectors having different views on certain rules and regulations, adding that some recommendations from inspectors were difficult or impossible to implement in practice. Some noted that supervision focuses primarily on negative aspects of improvement and felt that internal audits were more relevant and useful than governmental supervision, because the hospitals are leading their own problem solving.

If you have a written procedure and something happens, then they (red. inspectors) ask: "But why did you not do that?" Because the anatomy indicated differently (red. physician answers). "But it states in your written procedure that you should do it, right?" That is how a lawyer speaks compared to a physician...

$$
\text { - Medical doctor, head of clinic (15) }
$$

\section{DISCUSSION \\ The main findings}

According to the Quality Improvement Regulation, managers are responsible for implementation efforts and for the use of PDSA methodology. Our participants nevertheless described no change in their practice (related to quality and safety activities) solely due to this new regulatory framework. The introduction of the Quality Improvement Regulation was thus perceived by the participants as having no direct link with how they performed their work. Despite that, this study discovered structural and cultural changes to, and development of, quality improvement systems in hospitals in recent years. We argue that the structural and cultural changes that have happened (eg, annual quality and patient safety reports to the Norwegian Parliament, National Strategy for Quality Improvement in 
Health and Social Services (2005-2015), ${ }^{39}$ 'Patient Safety Program ${ }^{40}$ ), also included the revision of the previous Internal Control Regulations into a new regulatory framework. ${ }^{13}{ }^{48}$ Hence, the governmental development of the Quality Improvement Regulation appears to be part of that systemic change. Participants described several benefits with the Quality Improvement Regulation in terms of adaptation and flexibility to local context, and clinical autonomy as an inevitable element in hospital practice. Trust and a safe work environment were considered key factors to support adverse event reporting and learning processes in general. The latter was crucial if collaboration with external supervisory inspectors should positively influence hospital quality enhancement.

\section{Strengths and limitations of this study}

It is assumed essential to involve different types of stakeholders when researching the system-level phenomenon of risk-based management, where complexity, uncertainty and variation are key concepts. ${ }^{53} 69$ This study investigated hospital managers' perspectives and experiences with practical implications of a specific regulatory change. Lower level management implementation of the new regulatory requirements was given main attention in our study. It is thus a limitation that it only reports the perspectives of managers and no other stakeholders from different levels in the system, such as patients, fulltime clinicians, regulators. The perspectives of regulators and inspectors are presented in two separate research articles. ${ }^{37}$ The main study strength is the uncommon approach of involving hospital managers in healthcare regulation research, as they both legally and practically are responsible for improving quality and safety. An additional strength is that most participants had substantial clinical experience and/or stilled worked in the clinic environment, in addition to having management responsibilities, which provided the study with valuable insight into the complexity in hospital management. A limitation with this study is that the interviews focused on hospital managers own reflections and did not include any observational study of practice/implementation/change. Another limitation is that two out of four regional health trusts in the Norwegian specialist healthcare system were not included. This may have hampered valuable information about the implementation process and geographical variations since the support systems and routines for training managers differ from region to region. Guided by the information power, however, the sample size of 20 participants was adequate and supported our effort to ensure trustworthiness. ${ }^{57} 70$ We did nevertheless not discuss potential differences among participants belonging to the three different local health trusts (which could be viewed as a limitation), as we did not fully map resources, size and context of their quality advising units. However, all hospitals had established committees, boards and units related to quality improvement, and the structural and cultural changes reported in theme 3 reflected that overall systemic development.
Implementation, the capacity to adapt and the link to support systems

Healthcare regulation is tailored in various ways by the government, depending on the area. Some sectors are strictly governed by prescriptive rules (eg, medication-related issues). ${ }^{64}$ The idea with the Quality Improvement Regulation's design on the other hand was to provide managers with non-detailed goals for risk management-based implementation. With a non-detailed regulatory framework, the government does not specify how hospital managers should 'get there', built on ideas of local autonomy and context sensitivity. ${ }^{64}$ As our data revealed, improvisation and local adaptation is viewed as essential to hospital management, along with an acceptance that healthcare situations such as patient treatment, diagnosis or surgery can develop into unforeseen scenarios which cannot be planned for. Regulatory measures that are too standardised or prescriptive could adversely reduce the autonomy of managers and health personnel. Our findings illustrated that managers acknowledged that strict regulations could potentially affect and hamper patient safety in cases where flexibility could be beneficial to the outcome.

However, a high degree of system adaptive capacity could occasionally represent a disadvantage, for instance when a procedure is adjusted but leads to an unsuccessful or unacceptable outcome, ${ }^{67}$ or regulatory flexibility combined with a lack of interest in quality improvement work allows regulatees to deliberately ignore quality and safety expectations. Moreover, when choices and decisions are left to hospital organisations it creates considerable demand for internal systems to train managers, to establish systems for implementation support and IT solutions. This is echoed by past research on the growth of internal bureaucracy due to governmental deregulation of safety management. ${ }^{71}$ Hence, our study found a paradox in the systemic development of meetings, councils and committees at the administrative and management levels in hospitals to comply with regulatory requirements for quality and safety, while managers reported few changes at the sharp end; in clinic, related to implementation of quality and safety activities. It is reasonable to think that there is a disparity in hospital manager support across different hospitals. Thus, having autonomous responsibility for competences and management training could in turn lead to different priorities in different regions and hospitals. Variation in support systems and routines was nevertheless reflected in our results.

Moreover, previous research has emphasised skills and support to manage conditions of unexpected events, and that managers (due to prioritisation struggles) need guidance to understand what is operationally needed. ${ }^{72-74}$ Indeed, lack of knowledge and skills is perceived a significant barrier to quality improvement. ${ }^{75} 76$ We argue that our current study demonstrates that the Quality Improvement Regulation's non-detailed regulatory design, leaving implementation decisions to managers, could complicate managers' understanding of governmental expectations. This resonates especially since the requirements need to be translated before practically applied (eg, how to define 
specific hospital-conduct as reasonable; safe; prudent or what is adequate documentation). As successful implementation requires more than a change in regulatory rhetoric or design, our study indicates that support tools for managers to achieve the goals in a systematic way have not been fully developed yet. The disjunction between rhetoric and reality, or theory versus practice, is a familiar one in research on implementation of rules and regulations in healthcare. It is often referred to as a dichotomy of work as imagined versus work as done ${ }^{6677}$ This applies particularly to how requirements are trickled down the system to get resonance with those who do the actual implementation. ${ }^{31} 34357879$ When lower level managers fail to implement efforts because they are difficult to convert into practice or that the policies being implemented have a weak relationship with the core clinical tasks, a process of 'decoupling' has occurred. ${ }^{34}{ }^{35}$ The study of van de Bovenkamp et $a \ell^{0}$ revealed that hospitals needed to do a lot of interpretive work to make use of regulation; however, autonomy enabled this strategic work. Other studies have shown that additional resources and systems sometimes are needed to interpret and implement regulatory requirements. ${ }^{81}$ As detailed rules and regulations may often be perceived as barriers to implementation, focusing regulatory attention on defining the quality of processes and outcomes could potentially make regulatory expectations more feasible for practical implementation. On the other hand, some hospital managers may find less details less helpful, because most of the responsibility, decisions and operationalisation are left with them. What can be drawn from this is that it will be important to consider how regulatory expectations are designed in ways that enable hospital managers to put efforts into practical reality. This implementation gap may also partly be explained by the type of managers who oversee implementation efforts. With different leadership approaches debated in the literature, prior research has identified how clinical managers' sometimes struggle with role and identity. ${ }^{12}{ }^{82-86}$ Thus, to become interested in management, there ought to be awareness of meaning and purpose in management training, as it is first and foremost clinical work that is perceived meaningful to them. ${ }^{12}{ }^{86}$ Moving forward, it will be crucial to develop management practices that encourage quality improvement efforts, and encourage health personnel to participate. ${ }^{15} 87$ Putting clinicians in management roles, provided with adequate leadership and quality improvement training, is key to making improvement an embedded and inclusive activity in everyday clinical work-especially since clinical managers often have experienced the importance of flexible and adaptive behaviour firsthand. ${ }^{11} 1232$ Thus, the 'hybrid professional manager' might bridge professional management, clinical identity and engagement, constituting an important system factor underpinning successful quality improvement and implementation. ${ }^{8485} 88$

\section{PDSA—government favoured methodology for quality improvement}

Although the Quality Improvement Regulation manifested the PDSA logic, ${ }^{38}$ it did not independently explain if and why managers decided to put quality and safety activities on their agenda. Our findings indicated that clinicians worked with quality improvement, but they did not necessarily follow the PDSA-logic nor were they familiar with the Quality Improvement Regulation. Moreover, several participants described that measuring improvement efforts was challenging. This study links this to the assumption that everything is measurable according to the PDSA logic. ${ }^{89}$ In that sense, and alike our study, prior research has found some drawbacks in using PDSA in hospitals' quality improvement work. ${ }^{90-92}$ Although the PDSA methodology encourages learning and supports adaptation of interventions, its efficient use requires considerable training and organisational and managerial support. ${ }^{91}$ If PDSA is to remain at the core of regulatory design, then issues of organisational support and training need to be accounted for by regional health trusts and Government budgets.

Several alternative quality improvement methodologies exist. For instance, Six Sigma (define, measure, analyse, improve, control), Lean (identify waste; activities that do not add value), root cause analysis (identify the underlying causes; reactive in its approach), failure modes and effect analysis (identify potential adverse events, failures and hazards; proactive in in its approach) ${ }^{93}$ Commonly among these approaches is that they presuppose identification of a specific problem area or cause(es) before the next steps of action might be implemented. This could possibly make managers overlook certain areas that are not obviously apparent. Thus, based on the contextual reality of hospital managers, reflected in our findings about resources and lack of time, we argue that complex, non-linear processes are challenged by these methodologies. Moreover, systemic risk factors such as resources and time are embedded and often linked and interrelated when an adverse event occurs. ${ }^{94-97}$ Other organisational design considerations also seem important, beyond specific improvement methods. For instance, the inclusion of short, daily breaks to facilitate learning episodes may assist in improvement efforts. ${ }^{98}$ Organisational adaptations such as this could address some of the challenges identified by participants in this study, where systematic quality improvement in line with the Quality Improvement Regulation's PDSA logic, was viewed as too time consuming to justify full-scale implementation.

\section{Implications for clinicians and policy-makers—and future research}

This study is of relevance to both regulatory bodies and the management levels within hospitals. It adds some useful insights to development and implementation of future regulatory amendments in a Norwegian and in an international context. Moreover, the study highlights the importance of ensuring that any macrolevel quality improvement initiatives and regulatory requirements are accompanied by appropriate resourcing, support, and advanced preparation to ensure that it has the best possible chance of being implemented effectively. Our results therefore may contribute to theoretical 
development of macrolevel regulation, by implying how inclusive governance can add value to fill in the gap between work as imagined and work as done and support adaptive capacity as a positive element in quality improvement work. ${ }^{67}$ Additionally, our study highlights regional variation in management training and programmes for leadership development, which fuels the idea that it will be important to provide a minimum level of training to all hospital managers, regardless of organisational level and regional affiliation. Yet, there are some unanswered questions that speaks for future research, for instance:

- How to provide additional management support for implementation through adding 'practice facilitators'. ${ }^{72}$

- How to improve the collaboration between inspectors and hospital managers. ${ }^{99}$

- It would also be valuable to engage in cross-country comparative research to investigate how different regulatory regimes value flexibility in regulatory strategies for quality improvement and patient safety.

\section{CONCLUSION}

In this study, we explored how hospital managers work to improve quality and investigated their experiences with implementing the new Quality Improvement Regulation, provided to support management of quality improvement. The study showed that lack of time, competence and/or motivation, appears to limit the implementation of quality improvement efforts. While managers' work to improve quality does not solely depend on a specific regulatory framework, the Quality Improvement Regulation may be an instrument that over time, leads to structural and cultural change. In turn, it can push managers towards a shift in strategic learning focus and resource allocations. Ultimately, hospital managers' autonomy and their adaptive capacity and ability to tailor quality improvement efforts to local circumstances were key for the new Quality Improvement Regulation to have any relevant impact on hospital practice and for it to influence quality and safety activities.

\section{Author affiliations}

${ }^{1}$ SHARE - Centre for Resilience in Healthcare, Faculty of Health Sciences, University of Stavanger, Stavanger, Norway

${ }^{2}$ Department of Research, Stavanger University Hospital, Stavanger, Norway ${ }^{3}$ Department of Social Science, Western Norway University of Applied Sciences, Sogndal, Norway

${ }^{4}$ Department of Safety, Economics and Planning, University of Stavanger, Stavanger, Norway

${ }^{5}$ Centre for Health Innovation, Leadership and Learning, Nottingham University Business School, Nottingham, UK

Contributors All authors designed the study. SF0 conducted all interviews and transcribed 11 of these. Nine interviews were transcribed by a consultant. SF0 analysed the data, and SW and GSB read the interview transcripts and discussed categories and themes. SFO drafted the manuscript. All four authors made critical revisions to the manuscript's scientific content.

Funding This work was supported by the Norwegian Ministry of Education and Research; University of Stavanger, Norway and part of the Resilience in Healthcare Research Program which has received funding from the Research Council of Norway from the FRIPRO TOPPFORSK program, grant agreement no. 275367.
Competing interests None declared.

\section{Patient consent for publication Not required.}

Ethics approval The study did not collect specific patient information; thus, no approval from the regional committees for medical and health research ethics was required. Personal data derived from the study's interviews were notified to the Norwegian Centre for Research Data (NSD) (Ref. No: 381276, 1 October 2018), as required in line with the agreement between the University of Stavanger and the NSD. Every participant signed informed consent ahead of the interview.

Provenance and peer review Not commissioned; externally peer reviewed.

Data availability statement Data may be obtained from a third party and are not publicly available. Data retrieved from the interviews are not publicly available due to the risk of identification but may be available from the corresponding author upon reasonable request and with permission from the participant(s).

Supplemental material This content has been supplied by the author(s). It has not been vetted by BMJ Publishing Group Limited (BMJ) and may not have been peer-reviewed. Any opinions or recommendations discussed are solely those of the author(s) and are not endorsed by BMJ. BMJ disclaims all liability and responsibility arising from any reliance placed on the content. Where the content includes any translated material, BMJ does not warrant the accuracy and reliability of the translations (including but not limited to local regulations, clinical guidelines, terminology, drug names and drug dosages), and is not responsible for any error and/or omissions arising from translation and adaptation or otherwise.

Open access This is an open access article distributed in accordance with the Creative Commons Attribution Non Commercial (CC BY-NC 4.0) license, which permits others to distribute, remix, adapt, build upon this work non-commercially, and license their derivative works on different terms, provided the original work is properly cited, appropriate credit is given, any changes made indicated, and the use is non-commercial. See: http://creativecommons.org/licenses/by-nc/4.0/.

Author note SFO holds a Master of Laws (LL.M.) and MSc in Risk Management and Societal Safety and is currently a PhD candidate in Health and Medicine, SHARE - Centre for Resilience in Healthcare, at the University of Stavanger, Norway. GSB, MD, Adjunct professor, University of Stavanger; former Chief County Medical Officer Office; former Deputy Director General at the Norwegian Board of Health Supervision; Senior Adviser, Department of Research, Stavanger University Hospital. $\mathrm{CM}, \mathrm{PhD}$, Professor of Organisational Behaviour and Psychology, Centre for Health Innovation, Leadership and Learning, Nottingham University Business School and an Adjunct Professor at the University of Stavanger. SW, PhD, Professor of Quality and Safety in Healthcare Systems, SHARE - Centre for Resilience in Healthcare, at the University of Stavanger and Honorary Professor at the Australian Institute of Health Innovation, Faculty of Medicine and Health Sciences, Macquarie University, Australia.

ORCID iDs

Sina Furnes Øyri http://orcid.org/0000-0001-5348-1395

Geir Sverre Braut http://orcid.org/0000-0002-3337-4792

\section{REFERENCES}

1 Francis R. Report of the mid Staffordshire NHS Foundation trust public inquiry: Executive summary: Stationery office, 2013 Available: https://assets.publishing.service.gov.uk/government/ uploads/system/uploads/attachment_data/file/279124/0947.pdf [Accessed October 21, 2020].

2 Kirkup B. The report of the Morecambe Bay investigation, 2015 Available: https://assets.publishing.service.gov.uk/government/ uploads/system/uploads/attachment_data/file/408480/47487_MBI Accessible_v0.1.pdf [Accessed October 21, 2020].

3 Slawomirski L, Auraaen A, Klazinga N. The economics of patient safety. strengthening a value-based approach to reducing patient harm at national level. OECD 2017 https://www.oecd.org/els/healthsystems/The-economics-of-patient-safety-March-2017.pdf

4 Gandhi TK, Kaplan GS, Leape L, et al. Transforming concepts in patient safety: a progress report. BMJ Qual Saf 2018;27:1019-26.

5 Norwegian Directorate of Health. In Norwegian: Nasjonal handlingsplan for pasientsikkerhet OG kvalitetsforbedring 20192023. in English: National action plan for patient safety and quality improvement 2019-2023, 2019. Oslo. Available: https://www. helsedirektoratet.no/veiledere/ledelse-og-kvalitetsforbedring-ihelse-og-omsorgstjenesten/Nasjonal\%20handlingsplan $\% 20$ for $\%$ 20pasientsikkerhet\%20og\%20kvalitetsforbedring\%202019-2023. pdf/_attachment/inline/79c83e08-c6ef-4adc-a29a-4de1fc1fc0ef: 
94a7c49bf505dd36d59d9bf3de16769bad6c32d5/Nasjonal\% 20handlingsplan\%20for\%20pasientsikkerhet\%20og\%20kvalitetsf orbedring\%202019-2023.pdf [Accessed October 21, 2020].

6 Institute of Medicine. To err is human: building a safer health system. In: Kohn L, Corrigan J, Donaldson M, eds. Washington, DC: Institute of Medicine, 2000.

7 Batalden PB, Davidoff F. What is "quality improvement" and how can it transform healthcare? Qual Saf Health Care 2007;16:2-3.

8 Wears RL, Sutcliffe KM. Still not safe: patient safety and the MiddleManaging of American medicine. 1st edn. Oxford University Press, 2020.

9 Botwinick L, Bisognano M, Haraden C. Leadership guide to patient safety. IHI innovation series white paper. Cambridge, Massachusetts: Institute for Healthcare Improvement, 2006. https://pasientsikkerhetsprogrammet.no/om-oss/innsatsomrader/ ledelse-av-pasientsikkerhet/_/attachment/inline/b314ed6c-376746c5-a8a8-fc445aa94f68:1 ded2e5d159678cf61b9ebb357af4936 a3d37c81/ihi-leadership-guide-to-patient-safety.pdf

10 Künzle B, Kolbe M, Grote G. Ensuring patient safety through effective leadership behaviour: a literature review. Saf Sci 2010;48:1-17

11 Spehar I, Frich JC, Kjekshus LE. Clinicians' experiences of becoming a clinical manager: a qualitative study. BMC Health Serv Res 2012;12:421.

12 Spehar I, Frich JC, Kjekshus LE. Clinicians in management: a qualitative study of managers' use of influence strategies in hospitals. BMC Health Serv Res 2014;14:251.

13 Norwegian Ministry of Health and Care. In Norwegian: Forskrift om ledelse og kvalitetsforbedring i helse- og omsorgstjenesten. FOR-2016-10-28-1250. In English: Regulation on management and quality improvement in the healthcare services. Oslo: Norwegian Ministry of Health and Care Services, 2016. Available: https:// lovdata.no/dokument/SF/forskrift/2016-10-28-1250 [Accessed July $15,2020]$

14 Norwegian Ministry of Health and Care. In Norwegian: Lov 2. juli 1999 nr. 61 Lov om spesialisthelsetjenesten m.m. (spesialisthelsetjenesteloven). In English: Act of 2 July 1999 No. 61 relating to Specialist Health Care Services. Norwegian Ministry of Health and Care Services; 1999. Available: https://lovdata.no/ dokument/NL/lov/1999-07-02-61. [Accessed July 15, 2020].

15 Drew JR, Pandit M. Why healthcare leadership should embrace quality improvement. BMJ 2020;368:m872.

16 Brennan TA. The role of regulation in quality improvement. Milbank Q 1998;76:4:729-31.

17 Walshe K. Regulating healthcare: a prescription for improvement? McGraw-Hill Education, 2003.

18 Flodgren G, Pomey MP, Taber SA, et al. Effectiveness of external inspection of compliance with standards in improving healthcare organisation behaviour, healthcare professional behaviour or patient outcomes. Cochrane Database Syst Rev 2011;11.

19 Healy J. Improving health care safety and quality: reluctant regulators. Routledge, 2016.

20 Schaefer C, Wiig S. Strategy and practise of external inspection in healthcare services - a Norwegian comparative case study. Saf Health 2017;3.

21 Hovlid E, Frich JC, Walshe K, et al. Effects of external inspection on sepsis detection and treatment: a study protocol for a quasiexperimental study with a stepped-wedge design. BMJ Open 2017;7:e016213.

22 Macrae C, Hollnagel E, Braithwaite J, et al. Reconciling regulation and resilience in health care. Resilient Health Care. Ashgate, 2013.

23 Bal R, Stoopendaal AMV, van de Bovenkamp H. Resilience and patient safety: how can health care regulations contribute?. Ned Tijdschr Geneeskd 2015;159:A9614.

24 Stoopendaal A, de Bree M, Robben P. Reconceptualizing regulation: formative evaluation of an experiment with System-Based regulation in Dutch healthcare. Evaluation 2016;22:394-409.

25 Berg SH, Akerjordet K, Ekstedt M, et al. Methodological strategies in resilient health care studies: an integrative review. Saf Sci 2018;110:300-12.

26 Berg SH, Aase K. Resilient characteristics as described in empirical studies on health care. In: Wiig S, Falbruch B, eds. Exploring resilience. A scientific journey from practice to theory. Springer Open, 2019

27 Øyri S, Wiig S. Regulation and resilience at the macro-level healthcare system - a literature review. Proceedings of the 29th European Safety and Reliability Conference 2019. Editors: Michael Beer and Enrico Zio.

28 Wiig S, Schibevaag L, Tvete Zachrisen R, et al. Next-of-Kin involvement in regulatory investigations of adverse events that caused patient death. J Patient Saf 2019. [Epub ahead of print: October 22].

29 Wiig S, Haraldseid-Driftland C, Zachrisen RannveigT, et al. Next of kin involvement in regulatory investigations of adverse events that caused patient death. J Patient Saf. [Epub ahead of print: October 22, 2019].

30 Wiig S, Aase K, Billett S, et al. Defining the boundaries and operational concepts of resilience in the resilience in healthcare research program. BMC Health Serv Res 2020;20:330.

31 Leistikow I, Bal RA. Resilience and regulation, an odd couple? Consequences of Safety-II on governmental regulation of healthcare quality [published online ahead of print, 2020 Mar 30]. BMJ Qual Saf 2020. [Epub ahead of print: 2020 Mar 30].

32 Grote G. Leadership in Resilient Organizations. In: Wiig S, Falbruch $\mathrm{B}$, eds. Exploring resilience. A scientific journey from practice to theory. Springer Open, 2019.

33 Johannesen DTS, Wiig S. Why adopt ISO 9001 certification in hospitals? A case study of external triggers and sensemaking in an emergency department in Norway. Saf Health 2017;3:7.

34 van de Bovenkamp HM, Stoopendaal A, Bochove Mvan, et al. Tackling the problem of regulatory pressure in Dutch elderly care: the need for recoupling to establish functional rules. Health Policy 2020;124:275-81.

35 de Bree M, Stoopendaal A. De- and Recoupling and public regulation. Organ. Sci 2020;41:599-620.

36 Norwegian Ministry of Health and Care Services. In Norwegian: Klarere krav TIL ledelse. in English: clearer management requirements, 2016. Available: https://www.regjeringen.no/no/ aktuelt/klarere-krav-til-ledelse/id2518180/ [Accessed July 9, 2020].

37 Øyri SF, Braut GS, Macrae C, et al. Exploring links between resilience and the macro-level development of healthcare regulation- a Norwegian case study. BMC Health Serv Res 2020;20:762.

38 Deming WE. Out of the crisis, Massachusetts Institute of technology center for advanced engineering study, 1986.

39 Norwegian Directorate of Health. In Norwegian: Nasjonal strategi for kvalitetsforbedring i sosial- og helsetjenesten .Og bedre skal det bli! (2005-2015). In English: National Strategy for Quality Improvement in Health and Social Services (2005 - 2015). Oslo: Norwegian Directorate of Health; 2005. Available: https://www. helsedirektoratet.no/veiledere/oppfolging-av-personer-med-storeog-sammensatte-behov/metoder-og-verktoy-for-systematiskkvalitetsforbedring-for-helhetlige-og-koordinerte-tjenester/ de-seks-dimensjonene-for-kvalitet-i-tjenestene-er-sentralesjekkpunkter-i-forbedringsarbeidet/Og-bedre-skal-det-blinasjonal-strategi-for-kvalitetsforbedring-i-sosial-og-helsetjenesten2005-2015-IS-1162-bokmal.pdf//attachment/inline/ 985d47ad-c5cc-47e4-8e4d-2d3ae1a05bbe:cdbc34628eed68ec 59098b3a2f41e0f8a28a44ee/Og-bedre-skal-det-bli-nasjonalstrategi-for-kvalitetsforbedring-i-sosial-og-helsetjenesten-20052015-IS-1162-bokmal.pdf [Accessed October 25, 2020]

40 Norwegian Ministry of Health and Care Services. In Norwegian: Pasientsikkerhetsprogrammet I trygge hender 24-7. in English: program for patient safety. in safe hands 24-7. Available: https:// www.regjeringen.no/no/dokumenter/PasientsikkerhetsprogrammetI-trygge-hender-24-7/id2005291/ [Accessed October 10, 2020].

41 Deloitte. In Norwegian: Sluttrapport 2019. In English: evaluation of program for patient safety, 2019. Available: file:///C:/Users/2919684/ Downloads/Sluttrapport_Pasientsikkerhetsprogrammet\%20(1).pdf [Accessed October 21, 2020].

42 Norwegian Board of Health Supervision. In Norwegian: «Mens vi venter ....»-forsvarlig pasientbehandling i akuttmottakene? Rapport fra Helsetilsynet 2/2008. In English: Report. Available: https://www.helsetilsynet.no/historisk-arkiv/rapport-frahelsetilsynet/2008/forsvarlig-pasientbehandling-oppsummeringlandsomfattende-2007-akuttmottak-somatisk-spesialisthelset jeneste/ [Accessed October 21, 2020].

43 Norwegian Board of Health Supervision. In Norwegian: Krevende oppgaver Med svak styring. Rapport fra Helsetilsynet 5/2011. In English: Demanding tasks concerning weak management. Report. Available: https://www.helsetilsynet.no/publikasjoner/rapportfra-helsetilsynet/2011/krevende-oppgaver-med-svak-styringsamlerapport-tilsyn-2010/ [Accessed October 21, 2020].

44 Norwegian Board of Health Supervision. In Norwegian: Spesialisthelsetjenestens håndtering $\mathrm{AV}$ henvisninger $\mathrm{OG}$ utredning AV pasienter Med tykk- OG endetarmskreft. Rapport fra Helsetilsynet 4/2013. In English: report. Available: https://www. helsetilsynet.no/publikasjoner/rapport-fra-helsetilsynet/2013/spes ialisthelsetjenestens-handtering-av-henvisninger-og-utredningav-pasienter-med-tykk-og-endetarmskreft-oppsummering-avlandsomfattende-tilsyn-2012/ [Accessed October 21, 2020]. 
45 Norwegian Ministry of Health and Care Services. In Norwegian: Meld. St. 10 (2012-2013) God kvalitet - trygge tjenester - Kvalitet OG pasientsikkerhet I helse- OG omsorgstjenesten. in English: good quality - safe services - quality and patient safety in the health and care services. Available: https://www.regjeringen.no/no/ dokumenter/meld-st-10-20122013/id709025/ [Accessed October 21, 2020].

46 Norwegian Ministry of Health and Care Services. In Norwegian: NOU 2015:11. Med åpne kort. Forebygging og oppfølging av alvorlige hendelser i helse- og omsorgstjenestene. In English: White Paper 2015:11. Departementenes sikkerhets- og serviceorganisasjon. Oslo: Informasjonsforvaltning, 2015. Available: https://www.regjeringen.no/contentassets/daaed86b64c04f79 a2790e87d8bb4576/no/pdfs/nou201520150011000dddpdfs.pdf [Accessed October 21, 2020].

47 Norwegian Ministry of Health and Care Services. In Norwegian: Høringsnotat. In English: Hearing Memorandum. Oslo: Ministry of Health and Care Services, 2015. https://www.regjeringen.no/ contentassets/5a7d16bae77f4efe8f91af796c6f4b9c/horingsnotat forskrift styringssystem-1945587.pdf

48 Norwegian Ministry of Health and Care. In Norwegian: Forskrift om internkontroll $i$ sosial- og helsetjenesten. FOR-2002-12-20-1731. In English: Internal Control Regulation in the Healthcare Services. Oslo: Norwegian Ministry of Health and Care Services, 2002. Available: https://lovdata.no/dokument/LTI/forskrift/2002-12-201731 [Accessed July 15, 2020].

49 Norwegian Directorate of Health. In Norwegian: Veileder til forskrift om ledelse og kvalitetsforbedring i helse- og omsorgstjenesten. In English: Guidelines to Regulation on management and quality improvement in the healthcare services. Oslo: Norwegian Directorate of Health, 2017. https://www.helsedirektoratet no/veiledere/ledelse-og-kvalitetsforbedring-i-helse-ogomsorgstjenesten

50 Norwegian Ministry of Health and Care. In Norwegian: Lov 15. juni $2001 \mathrm{nr} .93$ Lov helseforetak m.m. (helseforetaksloven). In English: Act of 15 June $2001 \mathrm{nr} .93$ relating to Health Trusts. Oslo: Norwegian Ministry of Health and Care Services; 2001. Available: https://lovdata.no/dokument/NL/lov/2001-06-15-93\#KAPITTEL_1 [Accessed July 15, 2020].

51 Norwegian Ministry of Health and Care. In Norwegian: Oversikt over landets helseforetak. In English: Display of the country's health trusts. Oslo: Ministry of Health and Care Services; 2019. Available: https://www.regjeringen.no/no/tema/helse-og-omsorg/sykehus/ innsikt/oversikt-over-landets-helseforetak/id485362/ [Accessed October 21, 2020].

52 Norwegian Ministry of Health and Care Services. In Norwegian: Lederansvar i sykehus Rundskriv I-2/2013. In English: Circula on management in hospitals. Oslo: Norwegian Ministry of Health and Care Services, 2013. (Accessed October 21, 2020).

53 Øyri SF, Braut GS, Macrae C, et al. Investigating hospita supervision: a case study of regulatory inspectors' roles as potential co-creators of resilience. Journal of Patient Safety Accepted 2020.

54 Rasmussen J. Risk management in a dynamic Society: a modelling problem. Saf Sci 1997;27:183-213.

55 Diez Roux AV. A glossary for multilevel analysis. J Epidemiol Community Health 2002;56:588-94.

56 Anderson RA, Crabtree BF, Steele DJ, et al. Case study research: the view from complexity science. Qual Health Res 2005;15:669-85.

57 Graneheim UH, Lundman B. Qualitative content analysis in nursing research: concepts, procedures and measures to achieve trustworthiness. Nurse Educ Today 2004;24:105-12.

58 Yin RK. Case study research. design and methods. 88. SAGE Publications, 2014.

59 Braun V, Clarke V. Successful Qualitative Research - a practical guide for beginners. Thousand Oaks, CA: SAGE Publications, 2013.

60 Saunders B, Sim J, Kingstone T, et al. Saturation in qualitative research: exploring its conceptualization and operationalization. Qual Quant 2018;52:1893-907.

61 Furniss D, Barber N, Lyons I, et al. Unintentional non-adherence: can a spoon full of resilience help the medicine go down? BMJ Qual Saf 2014;23:95-8.

62 Hollnagel E, Woods DD, Leveson N. Resilience engineering: concepts and Precepts. Ashgate, Aldershot, 2006.

63 Hollnagel E, Braithwaite J, Wears RL. Resilient health care. Ashgate Publishing Limited, 2013: xxv.

64 Braithwaite J. The essence of responsive regulation. UBC Law Review 2011;44:475-520.

65 Hollnagel E. Safety-I and Safety-II. The past and future of safety management. T: aylor \& Francis Group, CRC Press, 2014.

66 Hollnagel E. Safety-II in practice. Developing the resilience potentials. Routledge, 2018.
67 Anderson JE, Ross AJ, Macrae C, et al. Defining adaptive capacity in healthcare: a new framework for researching resilient performance. Appl Ergon 2020;87:103111.

68 Blaikie N. Designing social research. Cambridge: Polity Press, 2010.

69 Engen OA, Lindøe PH. Coping with globalisation: robust regulation and safety in high-risk industries. In: Coze J-CL, ed. Safety science research: evolution, challenges and new directions. CRC Press, 2020.

70 Malterud K, Siersma VD, Guassora AD. Sample size in qualitative interview studies: guided by information power. Qual Health Res 2016;26:1753-60.

71 Størkersen K, Thorvaldsen T, Kongsvik T, et al. How deregulation can become overregulation: an empirical study into the growth of internal bureaucracy when governments take a step back. Saf Sci 2020;128:104772.

72 Olmos-Ochoa TT, Ganz DA, Barnard JM, et al. Sustaining effective quality improvement: building capacity for resilience in the practice facilitator workforce. BMJ Qual Saf 2019;28:bmjqs-2019-009950-1020.

73 Amalberti R, Vincent C. Managing risk in hazardous conditions: improvisation is not enough. BMJ Qual Saf 2020;29:60-3.

74 Pimentel MPT, Austin JM, Kachalia A. To improve quality, keep your eyes on the road. BMJ Qual Saf 2020;29:943-6.

75 Wilkinson J, Powell A, Davies $\mathrm{H}$. Are clinicians engaged in quality improvement? A review of the literature on healthcare professionals' views on quality improvement initiatives. The Health Foundation, 2011. Available: https://www.health.org.uk/publications/areclinicians-engaged-in-quality-improvement [Accessed June 30, 2020].

76 Dixon-Woods M, McNicol S, Martin G. Overcoming challenges to improving quality. Lessons from the Health Foundation's improvement programme evaluations and relevant literature, 2012. Available: https://www.health.org.uk/publications/ overcoming-challenges-to-improving-quality [Accessed June 30, 2020].

77 Anderson JE, Ross AJ, Back J, et al. Implementing resilience engineering for healthcare quality improvement using the care model: a feasibility study protocol. Pilot Feasibility Stud 2016;2:61.

78 Freeman T, Walshe K. Achieving progress through clinical governance? A national study of health care managers' perceptions in the NHS in England. Qual Saf Health Care 2004;13:335-43.

79 Erp J, Wallenburg I, Bal R. Performance regulation in a networked healthcare system: from cosmetic to institutionalized compliance. Public Adm 2020;98:46-61.

80 van de Bovenkamp HM, Stoopendaal A, Bal R. Working with layers: the governance and regulation of healthcare quality in an institutionally layered system. Public Policy Adm 2017;32:45-65.

81 Simon MdellaBadia. Compliance and high reliability in a complex healthcare organization. Front Health Serv Manage 2018;34:12-25.

82 Mintzberg H. Toward healthier hospitals. Health Care Manage Rev 1997;22:4:9-18.

83 Ham C. Improving the performance of health services: the role of clinical leadership. Lancet 2003;361:1978-80.

84 Fulop L, Day GE. From leader to leadership: clinician managers and where to next? Aust Health Rev 2010;34:344-51.

85 Fulop L. Leadership, clinician managers and a thing called "hybridity". J Health Organ Manag 2012;26:578-604.

86 Spehar I, Frich JC, Kjekshus LE. Professional identity and role transitions in clinical managers. J Health Organ Manag 2015;29:353-66

87 Soong C, Cho HJ, Shojania KG. Choosing quality problems wisely: identifying improvements worth developing and sustaining. BMJ Qual Saf. [Epub ahead of print: 29 April 2020].

88 Gauld R, Horsburgh S. Healthcare professionals' perceptions of clinical governance implementation: a qualitative New Zealand study of 3205 open-ended survey comments. BMJ Open 2015:5:e006157.

89 Taylor MJ, McNicholas C, Nicolay C, et al. Systematic review of the application of the plan-do-study-act method to improve quality in healthcare. BMJ Qual Saf 2014;23:290-8.

90 Curnock E, Ferguson J, Mckay J, et al. Healthcare improvement and rapid PDSA cycles of change: a realist synthesis of the literature, 2012. Available: https://nes.scot.nhs.uk/media/1389875/ pdsa_realist_synthesis.pdf [Accessed July 8, 2020].

91 Reed JE, Card AJ. The problem with Plan-Do-Study-Act cycles. BMJ Qual Saf 2016;25:147-52.

92 Knudsen SV, Laursen HVB, Johnsen SP, et al. Can quality improvement improve the quality of care? A systematic review of reported effects and methodological rigor in plan-do-study-act projects. BMC Health Serv Res 2019;19:683. 
93 Hughes RG, ed. Patient Safety and Quality: An Evidence-Based Handbook for Nurses. Rockville (MD): Agency for Healthcare Research and Quality (US), 2008.

94 Reason J. Understanding adverse events: the human factor. In: Vincent C, ed. Clinical risk management: enhancing patient safety. 2nd ed. London, UK: BMJ Books, 2001.

95 Reason J. Combating omission errors through task analysis and good reminders. Qual Saf Health Care 2002;11:40-4.

96 Hollnagel E. Barriers and accident prevention. Aldershot, UK: Ashgate Publishing Limited, 2004.

97 Cagliano AC, Grimaldi S, Rafele C. A systemic methodology for risk management in healthcare sector. Saf Sci 2011;49:695-708.

98 Basheer H, Allwood B, Lindsell C-M, et al. Never too busy to learn - how the modern team can learn together in the busy workplace. Royal College of physicians, 2018. Available: file:///C:/Users/2919684/ Downloads/Never\%20too\%20busy\%20to\%20learn_report\%20FINAL $0 \_0 \% 20(1)$.pdf [Accessed June 30, 2020].

99 Hovlid E, Teig IL, Halvorsen K, et al. Inspecting teams' and organisations' expectations regarding external inspections in health care: a qualitative study. BMC Health Serv Res 2020;20:627.
100 Darzi L, Johnson A. High quality care for all: NHS next stage review final report, vol. 7432. London: The Stationery Office, 2008.

101 Hood C, Rothstein H, Baldwin R. The government of risk: understanding risk regulation regimes. Oxford University Press, 2001.

102 Rausand M, Utne IB. Risikoanalyse- teori OG metoder. Fagbokforlaget, 2009.

103 Sollid S. Risikostyring I klinisk medisin. I: Pasientsikkerhet. Teori OG praksis. Karina Aase (red.). Universitetsforlaget, 2015.

104 Sheps S, Cardiff K. Looking at Success versus Looking at Failure: Is Quality Safety? Is Safety Quality? In: Hollnagel E, Braithwaite J, Wears RL, eds. Resilient Health Care. Ashgate Publishing Limited, 2013: xxv.

105 Aven T, Boyesen M, Njå O, et al. Samfunnssikkerhet. Universitetsforlaget, 2004.

106 SSB. In Norwegian: Statistikkområde. Helse: Pasienter på sykehus. In English: Statistics. Health: Patients in hospitals, 2020. Available: https://www.ssb.no/helse/statistikker/pasient [Accessed July 9, 2020].

107 Morgan D, Gmeinder M, Wilkens J. An OECD analysis of health spending in Norway", OECD Health Working Papers. 91. Paris: OECD Publishing, 2017. 